\title{
Editorial
}

\section{Waves and Ocean Structures}

\author{
Jaw-Fang Lee *(i) and Ray-Yeng Yang
}

Department of Hydraulics and Ocean Engineering, National Cheng Kung University, Tainan City 701, Taiwan; ryyang@mail.ncku.edu.tw

* Correspondence: jflee@mail.ncku.edu.tw

\section{check for} updates

Citation: Lee, J.-F.; Yang, R.-Y. Waves and Ocean Structures. J. Mar. Sci. Eng. 2021, 9, 305. https://doi.org/ 10.3390/jmse 9030305

Received: 26 February 2021

Accepted: 3 March 2021

Published: 9 March 2021

Publisher's Note: MDPI stays neutral with regard to jurisdictional claims in published maps and institutional affiliations.

Copyright: (c) 2021 by the authors Licensee MDPI, Basel, Switzerland. This article is an open access article distributed under the terms and conditions of the Creative Commons Attribution (CC BY) license (https:/ / creativecommons.org/licenses/by/ $4.0 /)$
This Special Issue concentrates on the problems of interactions between water waves and ocean structures. The methodologies used to solve the problems are either theoretical, numerical, or experimental approaches. New findings are particularly welcome. Coupling effects caused from either side of water waves or ocean structures are the main issue of the problems. Various types of ocean structures can be considered, such as fixed, movable, porous, flexible, free-floating, or with moorings.

The start of this Special Issue was right at the time when the Journal of Coastal and Ocean Engineering belonging to the Taiwan Society of Ocean Engineering ended. The guest co-editors Professor R-Y Yang and I believed that promising articles could find this Special Issue to submit for publishing. After all the paper collecting days and giving efforts, we are very happy to accept the results. The guest editors are particularly grateful for administration help and contribution from the assistant editor Ms. Zara Liu and others. With the conclusion of this year, we very much appreciate contributions from all authors. We will continue this Special Issue with extension II for the year 2021. Further, Professor Yang has the intention to promote another Special Issue; therefore, the co-guest editor will be replaced by Professor Ruey-Shan Shih. Welcome, Professor Shih. Together, we expect to accomplish another issue this year.

We encourage university scholars or industrial personnel with good research results to continue support and contribute to this Special Issue.

Various ocean structures are included in this issue, and coupling effects between waves and structures are emphasized. Lee et al. [1] presented a concept of a water column type wave power converter. Li et al. [2] considered submerged breakwaters. Lin et al. [3] studied an ocean current turbine system. Thiagarajan and Moreno [4] investigated oscillating heave plates in wind turbines. Chiang et al. [5] proposed an actuator disk model. Tseng et al. [6] investigated Bragg reflections of periodic surface-piercing submerged breakwaters. Lee et al. [7] analyzed caisson structures with a wave power conversion system installed. Yeh et al. [8] reported motion reduction in offshore wind turbines. $\mathrm{Wu}$ and Hsiao [9] considered submerged slotted barriers. Tang et al. [10] studied floating platforms with fishnets. Chen et al. [11] calculated mooring drags of underwater floating structures with moorings. Jeong et al. [12] estimated the motion performance of light buoys using ecofriendly and lightweight materials. Zhang et al. [13] considered vibrations of deep-sea risers. On the other hand, Shugan et al. [14] studied the effects of plastic coating on sea surfaces.

Author Contributions: Both authors contributed equally to this manuscript. All authors have read and agreed to the published version of the manuscript.

Funding: This research received no external funding.

Acknowledgments: We want to express our sincere thanks to all the authors and the reviewers.

Conflicts of Interest: The authors declare no conflict of interest. 


\section{References}

1. Lee, H.H.; Chen, G.-F.; Hsieh, H.-Y. Study on an Oscillating Water Column Wave Power Converter Installed in an Offshore Jacket Foundation for Wind-Turbine System Part I: Open Sea Wave Energy Converting Efficiency. J. Mar. Sci. Eng. 2021, 9, 133. [CrossRef]

2. Li, C.-Y.; Shih, R.-S.; Weng, W.-K. Visualization Investigation of Energy Dissipation Induced by Eddy Currents for a Solitary-Like Wave Passing over Submerged Breakwater Sets. J. Mar. Sci. Eng. 2020, 8, 834. [CrossRef]

3. Lin, S.-M.; Chen, Y.-Y.; Hsu, H.-C.; Li, M.-S. Dynamic Stability of an Ocean Current Turbine System. J. Mar. Sci. Eng. 2020, 8, 687. [CrossRef]

4. Thiagarajan, K.; Moreno, J. Wave Induced Effects on the Hydrodynamic Coefficients of an Oscillating Heave Plate in Offshore Wind Turbines. J. Mar. Sci. Eng. 2020, 8, 622. [CrossRef]

5. Chiang, Y.-C.; Hsu, Y.-C.; Chau, S.-W. Power Prediction of Wind Farms via a Simplified Actuator Disk Model. J. Mar. Sci. Eng. 2020, 8, 610. [CrossRef]

6. Tseng, I.-F.; You, C.-S.; Tsai, C.-C. Bragg Reflections of Oblique Water Waves by Periodic Surface-Piercing and Submerged Breakwaters. J. Mar. Sci. Eng. 2020, 8, 522. [CrossRef]

7. Lee, H.H.; Wu, T.-Y.; Lin, C.-Y.; Chiu, Y.-F. Structural Safety Analysis for an Oscillating Water Column Wave Power Conversion System Installed in Caisson Structure. J. Mar. Sci. Eng. 2020, 8, 506. [CrossRef]

8. Yeh, P.-H.; Chung, S.-H.; Chen, B.-F. Multiple TLDs on Motion Reduction Control of the Offshore Wind Turbines. J. Mar. Sci. Eng. 2020, 8, 470. [CrossRef]

9. Wu, Y.-T.; Hsiao, S.-C. Propagation of Solitary Waves over a Submerged Slotted Barrier. J. Mar. Sci. Eng. 2020, 8, 419. [CrossRef]

10. Tang, H.-J.; Huang, C.-C.; Yang, R.-Y. Numerical Study of the Influence of Fishnet Mesh Size on a Floating Platform. J. Mar. Sci. Eng. 2020, 8, 343. [CrossRef]

11. Chen, C.-T.; Lee, J.-F.; Lo, C.-H. Mooring Drag Effects in Interaction Problems of Waves and Moored Underwater Floating Structures. J. Mar. Sci. Eng. 2020, 8, 146. [CrossRef]

12. Jeong, S.-M.; Son, B.-H.; Lee, C.-Y. Estimation of the Motion Performance of a Light Buoy Adopting Ecofriendly and Lightweight Materials in Waves. J. Mar. Sci. Eng. 2020, 8, 139. [CrossRef]

13. Zhang, J.; Guo, H.; Tang, Y.; Li, Y. Effect of Top Tension on Vortex-Induced Vibration of Deep-Sea Risers. J. Mar. Sci. Eng. 2020, 8, 121. [CrossRef]

14. Shugan, I.; Yang, R.-Y.; Chen, Y.-Y. An Experimental and Theoretical Study of Wave Damping due to the Elastic Coating of the Sea Surface. J. Mar. Sci. Eng. 2020, 8, 571. [CrossRef] 